mgr inż. Adam Durzyński

dr inz. Zbigniew Durzyński, prof. nadzw.

dr Dariusz Kurpisz

mgr inz. Adam Sienicki

Instytut Pojazdów Szynowych ,TABOR”

\title{
Diagnostyka eksploatacyjna pojazdów szynowych
}

\begin{abstract}
W artykule scharakteryzowano wybrane procedury diagnostyczne oraz dostepne na rynku oprzyrzqdowanie umożliwiajace ich realizację. Szczególnq uwage zwrócono na diagnozowanie podzespotów układu biegowego zarówno w spoczynku jak $i$ w trakcie jazdy. Na podstawie wyszczególnionych badań przedstawiono koncepcje zagospodarowania stanowiska diagnostycznego.
\end{abstract}

\section{Wprowadzenie}

Celem niniejszego artykułu jest przedstawienie rodzaju i zakresu obowiązujących procedur diagnostycznych oraz określenie na ich podstawie koncepcji wyposażenia i zabudowy stanowiska diagnostycznego przeznaczonego do weryfikacji bieżących własności użytkowych pojazdu szynowego. Zaproponowano także sposób przetwarzania wyników przeprowadzonych badań w celu prognozowania czasu zużycia poszczególnych elementów i podzespołów.

Efektywne zarządzanie procesem eksploatacji pojazdu szynowego jest $w$ ścisły sposób powiązane z jego diagnostyka. Prawidłowo zaplanowane i przeprowadzone czynności diagnostyczne mogą nie tylko udzielić odpowiedzi na pytanie o bieżący stan zużycia wybranych podzespołów, zakres niezbędnych napraw, ale również posłużyć do oceny tempa zachodzących procesów zużycia, a w konsekwencji prognozowania żywotności poszczególnych elementów. Swoistym punktem odniesienia jest tutaj stan techniczny pojazdu w chwili rozpoczęcia jego eksploatacji. Informacji o nim dostarcza zespół szczegółowych badań przeprowadzonych stosownie do wymogów sprecyzowanych w $[6,7,8,9,10]$. W większości przypadków mają one charakter jednorazowy jak np.: pomiar drgań i sił dynamicznych, pomiar hałasu, oświetlenia, parametrów pracy zawieszenia, co w szerszym kontekście uniemożliwia ocenę zmiany tych wielkości na tle zachodzącego procesu eksploatacji. W tej sytuacji interesująca koncepcją jest okresowe powtórzenie niektórych badań o charakterze "jednorazowym" i odniesienie uzyskanych wyników do ich wartości początkowej. Efektem tego jest konieczność poszerzenia spektrum wykonywanych czynności diagnostycznych, a w konsekwencji uzupełnienia wyposażenia stanowiska diagnostycznego o dodatkowe oprzyrządowanie umożliwiające ich realizację. Niewątpliwą korzyścią płynąca z takiego sposobu podejścia jest natomiast możliwość prognozowania zużycia tych podzespołów. 


\section{Zakres i charakter badań stanowiskowych wy- konywanych przed dopuszczeniem do eks- ploatacji.}

Badania te wykonywane są dwuetapowo i mają na celu orzeczenie o zgodności właściwości eksploatacyjnych pojazdu szynowego z wymogami sprecyzowanymi w $[6,7,8,9,10]$. Jako pierwsze wykonuje się badania statyczne stanowiskowe, których głównym celem jest udzielenie odpowiedzi na pytanie o to czy pojazd jest wystarczająco bezpieczny, aby przeprowadzić badania ruchowe. Badania te posiadają zarówno charakter podstawowy, bezpieczeństwa jak i typu (tj. związany z specyficznymi rozwiązaniami technicznymi zastosowanymi przez producenta tylko w określonym typie pojazdu), a zaliczmy do nich:

- sprawdzenie charakterystyk układów biegowych pojazdu odpowiedzialnych za bezpieczeństwo jazdy (sztywność podłużnego i poprzecznego prowadzenia zestawów kołowych, moment oporowy wózka, sztywności skrętne reagujące na wichrowanie toru, sztywność poprzeczna zawieszenia nadwozia na wózkach oraz zdolność tłumienia drgań przez tłumiki)

- określenie pionowych nacisków kół na tor dla oceny rozkładu masy pojazdu i prawidłowości regulacji pierwszego i drugiego stopnia zawieszenia wózków (wybrane stany załadowania pojazdu)

- weryfikacje wymiarów pojazdu (współczynniki przechylania odpowiedzialne za skrajnię oraz wysokość urządzeń sprzęgających z innymi pojazdami),

- badanie stanu elementów hamulca ciernego podstawowego i postojowego (grubość klocków lub okładzin hamulcowych, grubość, czystość oraz chropowatość tarcz hamulcowych, sprawność przekładni i siłowników hamulcowych, szczelność instalacji powietrznej i sprawności technicznej układu sterującego pracą hamulca)

- określenie stanu powierzchni tocznej i obrzeży kół (grubość, wysokość i kąt pochylenia obrzeży oraz profil i chropowatość powierzchni tocznej), stanu powierzchni zewnętrznej osi zestawów kołowych a także stanu osadzenia kół (obręczy) na tych osiach

- sprawdzenie grubości blach (w tym perforacji wywołanych korozją) i stanu elementów złącznych konstrukcji nośnych pojazdu (ram wózków, belek nośnych i nadwozia, stan spoin, nitów i śrub odpowiedzialnych za wytrzymałość pojazdu i bezpieczeństwo jazdy)

- sprawdzenie ciagłości i izolacji instalacji elektrycznej pojazdu (rezystancji, impedancji, upływność i przerwanie obwodów) i funkcjonowania elementów przeciwporażeniowych
- określenie stanu sprawności akumulatorów (poziom naładowania, oporność wewnętrzną, elektrolit oraz układu kontroli jego ładowania)

- sprawdzenie poziomu emisji hałasu wytwarzanego przez urządzenia pojazdu w wybranych konfiguracjach ich działania (silnik spalinowy $\mathrm{z}$ osprzętem, elektro-energetyka układu napędowego i zasilania pokładowego, klimatyzacji i wentylacji)

- sprawdzenie parametrów agregatu prądotwórczego określających jego sprawność (moc silnika, jednostkowe zużycie paliwa, czystość filtrów powietrza, paliwa i oleju, czystość spalin, charakterystyka napięciowo-prądowa prądnicy dla wybranych obrotów i stanów obciążenia) oraz układu sterowania i kontroli jego pracy

- sprawdzenie parametrów działania trakcyjnych układów zasilania i napędów trakcyjnych (charakterystyki elektryczne - napięcia, prądy i obroty, stan elementów mechanicznych przeniesienia napędu - geometria zębów, luzy łożysk, szczelność olejowa)

- sprawdzenie odporności na przegrzanie urządzeń elektrycznych (prądnicy, prostowników, silników trakcyjnych, oporników rozruchu i hamowania oraz układów sterujących) oraz pary ciernej hamulca (klocków, kół jezdnych, okładzin i tarcz hamulcowych)

- sprawdzenie szczelności nadwozia na wodę i powietrze (przeciekanie poszycia pojazdu oraz wentylacja pasożytnicza)

- sprawdzenie poprawności działania wentylacji i klimatyzacji pojazdu (ilość świeżego powietrza, skuteczność ogrzewania i ochładzania - temperatury i moce cieplne)

- sprawdzenie poprawności działania systemów kontrolnych i pomocniczych wchodzących w skład wyposażenia dodatkowego (takich jak m. in. systemy sterowania drzwiami, komunikacji, łączności, informacji dla pasażerów, autodiagnozy itd.) z punktu widzenia bezpieczeństwa obsługi.

Kolejnym etapem jest przeprowadzenie $\mathrm{w}$ warunkach zbliżonych do eksploatacyjnych następujących badań i prób ruchowych:

- badanie charakterystyki dynamicznej pojazdu bezpieczeństwo przed wykolejeniem, stateczność jazdy oraz oddziaływanie na tor (ocena Y/Q na torach wichrowatych $\mathrm{w}$ warunkach quasistatycznych, występowanie poprzecznych drgań wózków i nadwozia przy szybkiej jeździe oraz sił pionowego Q i poprzecznego Y oddziaływania kół na szyny)

- ocena komfortu na drgania pojazdu (przyspieszenia na podłodze i siedzeniach), 
- ocena poziomu emisji hałasu na zewnątrz i do środka pojazdu przez układ jezdny, wibracje strukturalne ram wózków i nadwozia oraz urządzenia pokładowe (mikrofony kierunkowe na zewnątrz i pokładzie pojazdu oraz akcelerometry na membranach elementów podwozia i nadwozia pojazdu)

- ocena wentylacji i klimatyzacji pojazdu (pomiar mocy grzewczych i chłodzących, temperatur wewnątrz i na zewnątrz pojazdu w funkcji czasu) oraz składu powietrza podczas eksploatacji pojazdu (pomiar udziału dwutlenku węgla w powietrzu w wybranych miejscach wewnątrz pojazdu)

- ocena zdolności trakcyjnych i hamujących układu napędowego - planowana realizacja sił pociagowych lub hamujących w wybranych stanach wysterowania układu (siły wzdłużne na zestawach kołowych, prędkość jazdy, prądy i napięcia w układzie zasilania, obroty agregatu prądotwórczego, temperatury silników elektrycznych i oporników rozruchowych lub hamowania)

- ocena oporów ruchu pojazdu (realizacja ustalonych sił trakcyjnych lub jazda $\mathrm{z}$ wybiegu)

- ocena sprawności układu regulacji prędkości (czas reakcji i płynność wykonywania poleceń maszynisty przez układ, automatyczne wykonanie poleceń zdalnych na sytuacje awaryjne)

- ocena rzeczywistych dróg hamowania dla wybranych wariantów wysterowania hamulca (tylko hamulec cierny, tylko hamulec elektrodynamiczny, tylko hamulec szynowy oraz ich kombinacje) z pomiarem prędkości jazdy, ciśnień w układzie zasilającym, wielkości elektrycznych w układzie napędowym i zasilania hamulca szynowego

- ocena skuteczności układów kontroli poślizgów podczas napędzania i hamowania pojazdu (pomiar prędkości i przyspieszeń kół jezdnych oraz sił trakcyjnych lub hamujących w funkcji czasu)

- sprawdzenie grzania się łożysk maźniczych, prądnic i silników trakcyjnych (pomiar temperatury).

Każde $\mathrm{z}$ wymienionych badań wymaga przeprowadzenia serii szczegółowych prób służących ocenie wyznaczanych $\mathrm{w}$ nim parametrów, a to łączy się $\mathrm{z}$ koniecznością zastosowania metod pomiarowych oraz urządzeń zależnych od charakteru mierzonych wielkości i typu badanego pojazdu. Stąd dobór optymalnej metody diagnostyki i stosowanego w niej oprzyrządowania jest kluczowy ze względu na ocenę prawidłowości funkcjonowania diagnozowanego podzespołu. Istotnym ułatwieniem w ocenie bieżącej prawidłowości funkcjonowania poszczególnych podzespołów, na co zwrócono uwagę $\mathrm{m}$. in $\mathrm{w}$ [2] jest system autodiagnostyki. W przypadku lokomotyw elektrycznych typowy system sterowania i diagnostyki tworzą na stępujące układy:
- panel operatorski w kabinie 1

- panel operatorski w kabinie 2

- sterownik pulpitowy 1

- sterownik pulpitowy 2

- sterownik przetwornicy

- sterowniki napędu i hamowania ED

- sterownik tablicy pneumatycznej

- sterownik układu przeciwpoślizgowego

- sterownik układu uzdatniania powietrza

- sterownik pośredniczący

- sterownik prędkościomierza (rejestratora)

- sterownik diagnostyczny oraz modem GSM

- sterownik jazdy uproszczonej.

Komunikacja pomiędzy poszczególnymi elementami systemu w nowoczesnych pojazdach kolejowych odbywa się za pośrednictwem magistrali CAN.

Opracowany w Instytucie Pojazdów Szynowych „Tabor" system sterowania tablicy pneumatycznej, będący jednym $z$ wyżej wymienionych, zbudowano $\mathrm{z}$ sieci 9 sterowników połączonych magistralą RS232. Dla takiego układu opracowano model diagnostyczny układu hamulca lokomotyw elektrycznych. W wspomnianym modelu zastosowano symulator sygnałów wejściowych realizowany przez dedykowaną aplikację oraz sterownik centralny $\mathrm{z}$ modułem prądowym umożliwiającym generowanie dwóch sygnałów prądowych odpowiadających dwóm wybranym ciśnieniom.

Dodatkowo w modelu zastosowano sterownik mikroprocesorowy $\mathrm{z}$ modułem prądowym umożliwiającym generowanie dwóch sygnałów prądowych $0 \div 20 \mathrm{~mA}$. Sterownik ten razem z modułem realizuje uproszczony model symulatora ciśnień MCA i MCB.

Aplikacja umożliwia zadawanie sygnałów wejściowych i zapisywanie wszystkich sygnałów wejściowych i wyjściowych do pliku tekstowego na dysku komputera.

Symulator umożliwia zadawanie 60 sygnałów binarnych i 10 sygnałów analogowych po magistrali RS232. Umożliwia podgląd sygnałów wejściowych i wyjściowych on-line oraz realizuje zapis wszystkich danych do pliku tekstowego na dysku komputera.

Opracowanym modelem można testować wszystkie funkcje układu hamulca. Jedną $\mathrm{z}$ funkcji diagnostycznych jest próba hamulca dodatkowego. Wynik próby podlega automatycznej rejestracji.

\section{Zakres badań $w$ trakcie eksploatacji}

Dostęp w sposób ciagły do wszystkich informacji o parametrach pracy maszyn pokładowych (zasilania w energię, napędu, hamulca, drzwi, oświetlenia oraz obserwacji i komunikacji) i bezpieczeństwie ruchu jest ideałem, do którego należy dążyć. Jest to oczywiste, mimo że jeszcze na zbyt niskim poziomie. Natomiast tworzenie dodatkowej bazy danych o stanie pojazdu i jego urządzeń podczas 
eksploatacji nie jest oczywiste a może mieć charakter ciagły lub okresowy w zależności od charakteru zużycia eksploatacyjnego lub ważności procesu.

Od samego początku eksploatacji są okresowo przeprowadzane czynności diagnostyczne dotyczące oceny stanu elementów szybko zużywających się, takich jak wstawek klocków i tarcz hamulcowych oraz kół. Na niektórych pojazdach trzeba diagnozować również wykładziny gniazd czopów skrętu i ślizgów bocznych. Znacznie rzadziej ocenie podlega również stan wytrzymałości i kształtu pudła, jakości powłok malarskich oraz sprawność mechanizmów. W trakcie trwania eksploatacji celowe jest okresowe uzupełnienie wiedzy o dane wynikające $\mathrm{z}$ szeregu dodatkowych pomiarów, takich jak:

- pomiar drgań na pojeździe (maźnice, ramy wózków i nadwozie) oraz na urządzeniach wirujących (sprężarki, przetwornice, silniki itp.) za pomocą akcelerometrów,

- pomiar sił oddziaływania pojazdu na tor (np. poprzez naprężenia na osiach lub kołach zestawów kołowych) oraz sił reakcji łożysk w wirujących maszynach pokładowych,

- stanowiskowy pomiar nacisków pionowych kół jezdnych,

- lokalny pomiar hałasu wewnątrz pojazdu, pochodzący od podwozia i głównych urządzeń pokładowych,

- pomiar lokalnych temperatur powietrza na zewnątrz i wewnątrz pojazdu oraz ilość dwutlenku węgla,

- kontrola ślizgów pantografu,

- pomiar izolacyjności elektrycznej, temperatur i przewodności cieplnej urządzeń pokładowych,

- pomiar wielkości elektrycznych takich jak rezystancja, impedancja i charakterystyki półprzewodników,

- kontrola sprawności zaworów, przełączników i zamków,

- sprawdzanie stanu zanieczyszczenia filtrów i przewodów wentylacyjnych lub hydraulicznych maszyn.

\section{Opis dostępnej na rynku aparatury i koncepcja zagospodarowania stanowiska diagnostyczne- go}

Jak przedstawiono wcześniej prawidłowa realizacja czynności diagnostycznych łączy się $\mathrm{z}$ zastosowaniem odpowiedniej aparatury, a ich charakter uwarunkowany jest specyfiką diagnozowanego układu. Chociaż znacząca większość badań wymienionych $\mathrm{w}$ dokumentach normatywnych wywiera wpływ na bezpieczeństwo jazdy, to jednak jednymi z najważniejszych pod tym względem są badania układu biegowego i przeniesienia napędu.
Przykładowo, przedmiotem oceny diagnostycznej mogą być elementy wózków jezdnych:

- ramy wózków

- przekładnie trakcyjne

- łożyska maźnic

- zestawy kołowe,

- sprężyny nośne, drążki skrętne i przeguby.

Ocena wytrzymałości konstrukcji ram odbywa się już na etapie ich projektowania (obliczenia numeryczne), a następnie na podstawie wyników badań stanowiskowych odprężonego prototypu (w celu niwelacji naprężeń spawalniczych powstałych $w$ konstrukcji ramy stosuje się metodę odprężania wibracyjnego. Polega ona na obciążeniu konstrukcji drganiami wibracyjnymi zbliżonymi do jej częstotliwości jej drgań własnych a w efekcie wprowadzeniu zjawiska kontrolowanego rezonansu. Superpozycja naprężeń generowanych przez drgania i naprężeń resztkowych powoduje lokalne przekroczenie granicy plastyczności a w efekcie „rozładowanie” szczątkowego stanu naprężenia. Zadanie takie można zrealizować przy użyciu urządzenia VCM25). Zjawisko korozji materiału nie wywiera istotnego wpływu na ich żywotność. Biorąc pod uwage powyższe wystapienie jej uszkodzeń w trakcie prawidłowej eksploatacji jest bardzo mało prawdopodobne a wobec tego realna możliwość wystapienia awarii dotyczy głównie podzespołów wózka.

Jak dowodzi praktyka, najniebezpieczniejsze są awarie występujące w trakcie jazdy. Należy tu w szczególności wyróżnić sytuacje takie jak zagrzanie i zablokowanie hamulca, zagrzanie łożysk osi, deformacja bieżni kół, awaria przekładni trakcyjnej. Każda z nich może stać się bezpośrednią przyczyną katastrofy bądź doprowadzić do uszkodzenia torowiska. Interesującym sposobem rozwiązania jest tutaj System wykrywania stanów awaryjnych taboru kolejowego podczas jazdy ASDEK [1]. Stanowi on swego rodzaju urządzenie kontroli doraźnej stanu technicznego pojazdu w trakcie pracy. Zespół czujników wbudowanych $\mathrm{w}$ torach i współpracujących z systemem przetwarzania sygnałów dostarcza bieżącej informacji o stanie hamulców, łożysk osi, bieżni kół oraz naciskach na tor. W przypadku wykrycia nieprawidłowości informacja jest natychmiast przekazywana do najbliższego punktu kontroli ruchu taboru kolejowego, co pozwala na wyłączenie $\mathrm{z}$ ruchu zdefektowanej jednostki.

Badania stanowiskowe mają charakter prewencyjny, gdyż ich głównym celem jest ocena stanu technicznego podzespołów, a w efekcie wskazanie części, których uszkodzenia bądź stopień zużycia wskazują na to, że mogą one stać się przyczyną wystapienia awarii. Przedmiotem takich badań są: 
- naciski kół jezdnych w obrębie jednego wózka. Bardzo często różnią się one od wartości wynikających $\mathrm{z}$ teoretycznego rozkładu masy pojazdu na osie, co jest efektem tolerancji wykonania ramy wózka, tolerancji sprężyn resorowych oraz ich charakterystyk. Nierównomierny rozkład nacisków może powodować nierównomierne zużycie kół, zakłócenia spokojności biegu wózka oraz przyśpieszone zużycie torowiska. Oceny rozkładu nacisków pionowych można dokonać przy zastosowaniu stanowiska pomiarowego STOLEM [12]. Zbudowane jest ono z prasy hydraulicznej umożliwiającej symulacje nacisku do $200 \mathrm{kN}$ na jedno koło, oraz układu pomiaru nacisków pionowych kół (szyny ważące). Zaletą rozwiązania jest jego prostota, wadę stanowi możliwość diagnozowania tylko niezamontowanych wózków

- zawory rozrządcze i zespoły hamulcowe - tutaj rodzaj zalecanego urządzenia diagnostycznego związany jest bezpośrednio $\mathrm{z}$ charakterem badanego pojazdu. Oczekiwaniami stawianymi urządzeniu diagnostycznemu są tutaj: powtarzalność zadawanych przebiegów pneumatycznych, wysoka dokładność, wiarygodność oraz automatyzacja akwizycji uzyskanych wyników. W zakresie badań układów hamulcowych istotna jest także ocena stopnia zużycia powierzchni ciernej klocków.

Badania eksperymentalne i wstępne rozważania numeryczne [3] potwierdzają zmianę emitowanej w trakcie hamowania fali akustycznej w zależności od bieżącej grubości okładziny ciernej. Interesującym sposobem pomiaru generowanej fali akustycznej jest zastosowanie mikrofonów kierunkowych sprzężonych z systemem akwizycji i przetwarzania sygnału.

- zestawy kołowe - szczególną uwage należy zwrócić na stopień zużycia powierzchni tocznej koła oraz możliwość wystąpienia mikropęknięć zarówno w jego obrębie jak i osi zestawu kołowego. Oś zestawu kołowego poddana jest złożonemu stanowi obciążenia pochodzącemu od działania związanych $\mathrm{z}$ masą pojazdu obciążeń zginających i występujących w chwili rozruchu oraz hamowania obciążeń skręcających, na co zwrócono uwagę w [11]. Głównym zagrożeniem są tutaj pęknięcia zmęczeniowe. Ich wykrycia i lokalizacji można dokonać posługując się metodami rentgenowskimi, magnetoskopowymi bądź defektoskopii ultradźwiękowej. Istotna może także okazać się ocena wizualna stanu powierzchni osi obejmująca źródła i stopień korozji oraz ubytki materiału spowodowane uszkodzeniami mechanicznymi. Miejsca takie wprowadzają efekt karbu, a w efekcie mogą stać się zalążkiem mikropęknięć zmęczeniowych.
- wpływ wichrowatości toru na prace zawieszenia. Tutaj efektywnym rozwiązaniem jest urządzenie TENSAN [13]. Umożliwia ono ocenę prawidłowości pracy zawieszenia poprzez zastosowanie procesu wymuszonego wichrowania toru pod wózkiem. Sterowany komputerowo układ siłowników wymusza ruchy pionowe poszczególnych kół oraz dokonuje bieżącej rejestracji wymaganej przez normę siły nacisku koła i ugięcie sprężyn. Końcowym efektem jest wykreślenie pętli histerezy, co umożliwia wykrycie innych usterek w zawieszeniu. Urządzenie dostępne jest w kilku wersjach, w tym dedykowane do badań lokomotyw.

- urządzenia i aparaty pomocnicze - interesująca metoda jest analiza widma fali akustycznej emitowanej przez pracujące urządzenia. Znajomość parametrów fali akustycznej (takich jak amplituda i częstotliwość) odpowiadającej prawidłowej pracy urządzenia wsparta o umiejętność wyselekcjonowania emitowanych przez nie częstotliwości $\mathrm{z}$ ogółu mierzonych, pozwala $\mathrm{z}$ dużą dokładnością wskazać miejsce uszkodzenia. Realizacja tej metody wymaga jednak stworzenia systemu akwizycji i przetwarzania sygnału. Odbiór sygnału najlepiej realizować posługując się mikrofonami kierunkowymi a do jego przetwarzania wykorzystać transformatę falkowa. Uzyskane w końcowym efekcie widmo fali akustycznej badanego urządzenia porównywane jest z wzorcem.

- instalacje i urządzenia elektryczne - tutaj jak podkreślono w [4] należy zwrócić uwagę na stan parametrów krytycznych, do których zaliczamy:

- okres użytkowania ogniw galwanicznych,

- liczbę cykli ładowania rozładowania akumulatorów,

- przyrost temperatury podczas pracy, -napięcie i prąd ładowania, rozładowania akumulatorów.

Prognozowanie stanu zużycia źródeł pierwotnych jak i wtórnych może być realizowane poprzez wczytanie do pamięci trwalej pojazdu granicznej daty użytkowania (źródła pierwotne) lub maksymalnej liczby cykli ładowań i rozładowań (źródła wtórne). W obu przypadkach system powinien ze stosownym wyprzedzeniem informować użytkownika o konieczności wymiany źródła na nowe. W przypadku braku wspomnianej możliwości należy kontrolować końcową datę eksploatacji, bądź bieżącą liczbę cykli.

- charakterystyka i właściwości trakcyjne - tutaj ocenie diagnostycznej (w warunkach polowych na trasie) podlegają możliwości rozruchowe na tle zachowania warunków przyczepności. Zadanie to realizowane jest przez rejestrację cyfrową a 
następnie przetwarzanie parametrów elektrycznomechanicznych takich jak:

- prędkość liniowa pojazdu

- droga zespołu trakcyjnego

- napięcie zasilania zespołu trakcyjnego

- natężenie prądu pobieranego przez zespół trakcyjny

- natężenie prądu pobieranego przez falowniki w wagonie.

Rejestracji parametrów cyfrowych i ich analizy można dokonać tak, jak opisano w [5], tj. odpowiednio przy zastosowaniu rejestratora cyfrowego firmy GOULD typu TA11 oraz programu Dasa View II. Istotną rzeczą jest tutaj stwierdzenie czy w trakcie rozruchu realizowanego w zmieniających się warunkach (szyny suche, szyny mokre, stan próżny, stan pełnego załadowania) zachowane są wymagane wartości przyspieszeń oraz czy nie występuje zjawisko poślizgu koła na szynie.

\section{Podsumowanie}

Przeprowadzone i aktualnie realizowane badania oraz analizy możliwości oceny bieżącego stanu pojazdu kolejowego oraz prognozowania jego krótkoterminowego stanu wskazują na celowość systematycznego opracowywania i wdrażania specjalizowanych stanowisk diagnostycznych wspartych odpowiednio wydajnym zapleczem komputerowym.

Takie stanowiska pozwolą w krótkim czasie, co ma znaczenia dla wskaźnika gotowości technicznej, a ten przekłada się na wynik ekonomiczny, wskazać te podzespoły wagonu, które będą wymagały naprawy lub wymiany. Racjonalne wykonywanie prac przeglądowo-naprawczych w oparciu o wiedzę o aktualnym i prognozowanym stanie podzespołów pozwoli w porównaniu do rutynowego działania opartego na danych statystycznych: przebieg i czas eksploatacji pozwoli docelowo znacznie ograniczyć koszty eksploatacji.

Ze względu na znaczącą dominację w taborze kolejowym wagonów towarowych ze względu na ich liczbę celowe byłoby skoncentrowanie się na nich w pierwszym okresie rozwijania eksploatacyjnych systemów diagnostycznych.

\section{Literatura}

[1] ASDEK - specyfikacja techniczna urzqdzenia. Firma TENS

[2] Durzyński Z.: Katalog uszkodzeń i usterek systemów na tle architektury pojazdu. Pojazdy Szynowe 3/2012

[3] Kurpisz D., Durzyński A., Sienicki A.: Prognozowanie stanu zużycia klocka hamulcowego na podstawie parametrów sygnału akustycznego. Pojazdy szynowe 2/2013

[4] Eastowski M.: Ocena i prognozowanie stanu pokładowych chemicznych źródet energii elektrycznej. Pojazdy Szynowe 3/2012

[5] Oporowski M.: Badania właściwości trakcyjnych elektrycznego zespolu trakcyjnego typu 33WE. RP0805. IPS Tabor 2012

[6] PN-EN ISO 3095:2005. Kolejnictwo. Akustyka. Pomiar hałasu emitowanego przez pojazdy szynowe

[7] PN-EN ISO 3381:2011. Kolejnictwo. Akustyka. Pomiar hałasu wewnqtrz pojazdów szynowych

[8] PN-EN 12663:2010E. Kolejnictwo. Wymagania konstrukcyjno-wytrzymałościowe dotyczace pudet kolejo-wych pojazdów szynowych. Cz. 1. Lokomotywy $i$ tabor pasażerski (i metoda alternatywna dla wagonów towarowych. Cz. 2. Wagony towarowe.

[9] PN-EN 13749:2011E. Kolejnictwo. Zestawy kołowe $i$ wózki. Metody określania wymagań konstrukcyjnych dla ram wózków.

[10] PN-EN 14363:2007P. Kolejnictwo. Badania wtaściwości dynamicznych pojazdów szynowych przed do-puszczeniem do ruchu. Badania właściwości biegowych i próby stacjonarne.

[11] Sobaś M.: Diagnostyka osi zestawów kołowych układów biegowych pojazdów trakcyjnych i tocznych. Pojazdy Szynowe 4/2010

[12] STOLEM - specyfikacja techniczna urzadzenia. Firma TENS

[13] TENSAN. Systemy do kontroli oceny stanu technicznego i regulacji zawieszenia taboru kolejowego - specyfikacja techniczna urzqdzenia. Firma TENS. 